\title{
JUDICIAL ACTIVISM - AN ASSET TO JUDICIARY BY INDIAN CONSTITUTION
}

\section{Mr. S S Hasani}

\begin{abstract}
Constitution means the structure of a body, organism or organization i.e. what constitutes it or of what it consists of. Constitution of a country spells out the basic fundamental principles or established precedents on which the state is organized. It lays down the structure of the political system under which its people are to be governed. It establishes the main organs of the State-the legislature, the executive and the judiciary, demarcates their responsibilities and regulates their relationships with each other and with the people. All authority in the hands of any organs, institutions or functionaries of the state flow from the Constitution. In a country like ours, adopting a written Constitution which mandates Judicial Review of the constitutionality of State activity in cases needing it and the laws enacted by legislature, the role of Judiciary cannot be restricted to the primitive function of dispensing justice. The role of judiciary in enforcing judicial review, must for all purposes keep the Government in good tune with the changing times and it should not be allowed to drift to become anachronistic or out of reasoning with the need of the day.
\end{abstract}

\section{INTRODUCTION}

The Constitution is a legal document having a special legal sanctity which sets out the framework and the principal functions of the organs of the government of a state and declares the principles governing the operation of those organs. All constitutions are the heirs of the past as well as the testators of future. The law of the Constitution of a country seeks to establish the fundamental organs of government and administration, lays down their structure, composition, powers and principle functions, defines the interrelationship of one organ with another and regulates the relationship between the citizen and the state more particularly the political relationship. 
Constitutional morality would mean an effective coordination between conflicting interest of different people and the administrative cooperation to resolve them amicable without any confrontation amongst the various groups working for the realization of their ends at any cost. For, Dr Babasaheb Ambedkar, moral fabric of the society, governed as well as the governance must be strong. In other words, public conscience, moral order and Constitutional morality-ethos of politicians, that constitute the core of policy making, must be very sound and strong if democracy is to survive for long period of progress and prosperity for the common people ${ }^{1}$.

A constitution can perform many functions in a modern state. One of these tasks is to serve as a deposit for a cluster of a society's fundamental political values. A Constitution can reflect these values in substantive ways by guaranteeing Fundamental Rights and in procedural ways by providing remedies. It also reflects society's basic values in 'allocative ways'. It mirrors basic values about who shall govern and in what direction. In addition to structuring and 'allocating goals', through its institutional arrangements and commandments, the Constitution reflects a particular vision of a good and achievable community life.

In this backdrop wherein the Constitutional scheme has set an independent judiciary to deliver their judgments without any pressure and fear, it is naturally expected that "judicial discipline" is maintained so that the society can be assured of fairness, integrity and honesty in each judge.

\section{JUDICIAL ACTIVISM}

The dismal state of affairs had been recorded by the Apex Court in Sompal Sing Vs. Sunil Rathi ${ }^{2}$, Wherein the observations of the High court as to how an appeal against its order granting bail should be decided by the SC was totally disapproved by the SC . The SC considered the order of the High Court as being subversive of judicial discipline and id not consider it proper to say anything further. The facts of the case were that Sunil Rathi had been initially granted bail by the High Court in 2003. This order was challenged by the complainant Sompal Singh by filing an LSP. By inserting it, the high Court SC cannot intervene in the order of the High Court... order that overrules the Constitutional framework of the judiciary. In a unified hierarchical judicial system which India has accepted under its Constitution,

\footnotetext{
${ }^{1}$ Kashyap Subhash C, "Development of Indian Polity, Governance and Constitutional Culture", p. 2

${ }^{2}(2005) 1$ SCC 1
} 
vertically the SC is placed over the High Courts. As a superior forum the SC is granted the jurisdiction to issue corrective measures and to nullify, reverse, confirm or modify the decree or order of the forum appealed against. It is not for any court to tell the superior court as to how a matter should be decided by and when an appeal is taken against its decisions to that superior court. This order was considered as subversive of judicial discipline.

Judicial activism is a term used for a necessary creative activity of the judiciary. Article 141 of the Constitution authorizes the SC to establish law. Article 13 which empower the Judges to declare any law null and void, if it was found to be against the spirit of the fundamental rights enshrined in the Constitution. It also keeps judiciary active by removing its inertia to fulfil the constitutional goals.

Webster's Dictionary assigns the meaning 'being active to the term activism'. In this sense every Judge is, or at least should be activist, so long one decides, in whatever way one may choose to decide.

According to Justice Bhagwati Judicial Activism in India is being used or achieving distributive justice which is otherwise labelled as "Social Justice". Judicial Activism is simply for ensuing the systematic enforcement of court orders and the rule of law while juristic/judicial activism is the power of the Judges to interpret and perforce creative law. Judicial activism follows from the failure of the executive to adhere to law. The more responsible the executive, the lesser the judicial activism, but juristic/judicial activism flows from the Judges.

The term judicial activism is used with reference to the judicial decisions in various fields. Its areas are widening such as public interest litigations, writ petitions under Article32, interpretations of Articles 14, 19, 21, etc. Terms judicial activism is interpreted in different ways.

A democracy stand on our majestic pillars namely, the three State organs, the Legislature, Executive, Judiciary, and the Press. According to Montesquieu, these three organs of the State should have well defined and circumscribed areas of functions and powers so that one does not transgress upon others. No organ has an over powering or domineering role to play over others and in that sense they all stand on the same pedestal. The constitution of India also honours this separation of powers between Legislature, Executive and Judiciary, though not in its rigid form ${ }^{3}$. India has a parliamentary executive as in England, as the Council of Ministers is to consist of the members of Legislature; however judiciary has to be

\footnotetext{
${ }^{3}$ Constitution of India, Article 75(5) and 164(4)
} 
separate and independent ${ }^{4}$. In the scheme of the Constitution, the judiciary has a unique role to play. The Courts are intermediary between the people and other organs of the State in order to keep the latter within the parameters delineated by the Constitution ${ }^{5}$.

Justice Anand has said that judicial activism was an expression incapable of precise definition and activism was a word of convenience. ${ }^{6}$ Referring to the incorrect interpretation of the term judicial activism Justice J.S. Verma said that ordinary judicial activism meant the access to justice to the common man and their enforcement of his fundamental rights ${ }^{7}$.

The framers of our Constitution of India provided powers to the Judiciary in Articles : Art 32 for the SC of India and Art 226 for the High Courts in India and armed them with powers to issue directions, orders or writs and these powers include the powers in the nature of habeas corpus, mandamus, certiorari, prohibition and quo-warranto.

The powers conferred in the SC under Art 32 are exclusively for the enforcement of Fundamental Rights ${ }^{8}$. The power conferred in the High Courts in India under Art 226 include in addition to the powers bestowed on the SC are:

- For the enforcement of any of the rights enshrined in Part III of the Constitution of India.

- For any other purpose. This power is wider than the powers conferred in Art 32.

The Hon'ble SC in Basappa vs T.Nagappa ${ }^{9}$ clarified that the SC through Art 32 and the High Courts in India through Art 226 are bestowed with enormous powers to exercise in issuing the Writs in the nature of habeaus corpus, mandamus, quo-warranto, prohibition and certiorari, depending on the need of the case for the enforcement of fundamental rights. In addition to these, the Constitution bestowed a special power in the high Court to entertain petitions for "other purposes" too.

\section{Grounds for invoking Judicial Review:}

The Judicial Review can be invoked in the following manner:

- Ultra Vires

- Abuse of Misuse of Discretionary Powers

- Error apparent on the face of record.

\section{Ultra Vires:}

\footnotetext{
${ }^{4}$ Constitution of India, Article 50

${ }^{5}$ Kartar Singh v State of Punjab, (1994) 3 SCC 509

${ }^{6}$ Times of India, 2.11.1997

${ }^{7}$ Hindustan Times, 23.2.1997

${ }^{8}$ Lakshmikanth A (Prof), Precedent in Indian Law

${ }^{9}$ AIR 1954 SC 440
} 
The doctrine of ultra vires is considered is one of the salient features of the Constitution of India. This ground is used when there is a person or a body does a duty which is beyond the jurisdiction. The doctrine of ultra vires is the edifice on which the entire on which the entire adjudication is build and the power generating ground for the SC or High Court to check miscarriage of justice.

The other grounds of Judicial Review, apart from the Doctrine of Ultra vires are:

- The Abuse of Power.

- Illegality.

- Irrationality

- Denial of Natural Justice

- Jurisdiction

- Justifiability

The doctrine of Ultravires has been used in many of the Constitutional lapses. The Judicial Review works out to the advantage of an affected person, as we seen in the issuance of the Writs.

\section{CONCLUSION}

No doubt Public Interest in India brought revolutionary changes in Justice delivery system but some people like Justice Hidayatullah and Justice Tuljapurkar argued Public Interest Litigation should not be encouraged at the cost of regular litigation. But the SC of India encouraged Public Interest Litigation to deliver the Justice to the door steps of the poor, needy, destitute, oppressed and depressed classes of the society.

It is criticized on the ground that it can be misused for private motive or political ends. To avoid this defect, the Court has expressed the view that the person who moves the Court for judicial redress must be acting bona fide with a view to vindicating the causes of justice and if he is acting for personal gain or private profit or out of political motivation or other oblique of such person and must reject it.

To avoid the danger of persons dressing up their personal grievance in public interest garb, the Court has adopted the view that it is not meant for correcting individual wrong or injury. The view of the Court has been that as far as possible it should not entertain cases of individual wrong or injury at the instance of a third party.

The SC, by its own judge-made law and procedure, has become one of the most powerful Institutions. It is not a Court of limited jurisdiction of only dispute settling like the 
$\mathrm{SC}$ as we know in any democracy. Alost from the beginning the SC has been a law democracy.

The Court's sincere desire to do justice to the commoner and to shake a wooden bureaucracy is undoubted but increasingly it is whittling down its prestige any issuing administrative precepts which the authorities find difficult to implement or which the Court has non institutional means and authority to supervise and enforce them. The reality of the situation is that the judicial branch is simply not equipped to be legislative or administrative. Hence the need for a sparing use of judicial power in demarcated fields of judicial manageability.

\section{REFERENCES}

1. B.Shiva Rao, The Framing of India's Constitution ${ }^{e e}$, A Study, Tripathi.

2. Basu, D.D. „Introduction to the Constitution of Indiaa ${ }^{\text {ee }}$, 18th Edn.,

3. D.D. Basu, Shorter Constitution of India ,14th Edition,

4. Dr. J.N. Pandey, "Constitutional Law of India”, 40th Edition, Central Law Agency.

5. Dr. Justice Gajendra Gadkar, The Constitution of India, its philosophy and postulates' of 1969 Edn.

6. Prof. Om Prakash, "Religion and Society in Ancient India", 1985 Edition

7. Prof. Upendra Baxi, „The Struggle for the Re-definition of Secularism in India ${ }^{e e}$, Social Action, Vol. 44, 1994.

8. Subhash. C. Kashyap, "Blueprint of Political Reforms", Shipra Publications, Delhi, The Complete Works of Swami Vivekananda, Vol. V, New Delhi.

9. V.D. Mahajan, “Ancient India”, 5th edition.

10. V.N.Shukla, Constitution of India, 10th ed., Eastern Book Company.

S S Hasani,
Assistant Professor,
NTVS College of Law,
Nandurbar (MS)

